\title{
PROSES PENGAMBILAN KEPUTUSAN DENGAN KONSEP BERFIKIR KRITIS
}

\author{
Sri Lailan Nazmi Saragih \\ Email : lailansaragih9@gmail.com
}

\begin{abstract}
ABSTRAK
Penting bagi perawat untuk mampu mengambil keputusan klinis dengan melibatkan pasien dan keluarga dalam asuhan keperawatannya sehingka proses keperawatan yang diberikan kepada klein ini diarahkan sebagai proses refleksi baik bagi perawat ataupun klien. Tujuan nya adalah untuk mengetahui cara pengambilan keputusan klinis keperawatan dengan cara berfikir kritis. Perawat membutuhkan cara berpikir kritis dalam praktiknya. Berpikir kritis akan berguna untuk pengambilan keputusan dalam menetapkan kondisi pasien atau klien perawat tersebut. Kesalahan dalam menetapkan kondisi pasien akan mempengaruhi kualitas kan kuantitas perawatan yang diberikan kepada pasien tersebut. Dalam bertugas, perawat juga menggunakan diagnosis keperawatan agar perkembangan kondisi kesehatan pasien dapat lebih terdata dan dapat ditetapkan pelayanan-pelayanan yang akan diberikan selanjutnya
\end{abstract}

\section{Kata Kunci : Keputusan Klinis, Berpikir Kritis, Proses Keperawatan}

\begin{abstract}
It's important for nurses to be able to make clinical decisions by involving patients and families in nursing care so that the nursing process that is given to the cline is directed as a reflection process for both the nurse and the client. The aim is to find out how to make clinical nursing decisions by means of critical thinking. Nurses need a critical way of thinking in practice. Critical thinking will be useful for decision making in determining the condition of the patient or nurse client. Errors in determining the patient's condition will affect the quality of the quantity of care given to that patient. In their duties, nurses also use nursing diagnoses so that the development of the patient's health conditions can be more recorded and services to be provided can be determined later.
\end{abstract}

Keywords: Clinical Decisions, Critical Thinking, Nursing Process 


\section{LATAR BELAKANG}

Dalam menjalankan tugasnya, perawat tentu akan dihadapkan pada suatu kondisi dimana perawat tersebut akan memutuskan tentang kondisi kesehatan klien atau pasien yang ia tangani. Kondisi kesehatan pasien yaitu terdiri dari pasien yang sehat dengan pasien yang sakit. Pemikiran kritis akan sangat dibutuhkan karena menentukan skala kondisi kesehatan pasien tentu bukanlah hal yang mudah untuk dilakukan.

Mengambil keputusan secara tergesa-gesa ataupun tidak tepat akan mempengaruhi kualitas serta kuantitas pelayanan kesehatan pasien. Apabila sang perawat tidak berhatihati. Terdapat kemungkinan pasien akan menerima perawatan yang tidak sesuai dengan apa yang dibutuhkan.

Untuk membantu perawat dalam mendata dan memutuskan kondisi kesehatan pasien, perawat dibantu dengan sebuah catatan yang disebut diagnosa. Diagnosa berisi tentang kondisi pasien secara spesifik. Diagnosa dapat dijadikan sebuah acuan bagi pelayanan yang akan diberikan kepada pasien agar lebih cepat dan tepat.

Pengambilan keputusan klinis akan memperlihatkan perbedaan antara perawat dengan staf teknis, yaitu perawat akan cepat bertindak ketika kondisi pasien menurun mendeteksi masalahnya dan berinisiatif untuk memperbaikinya. Benner (1984) berpendapat bahwa pengambilan keputusan klinis sebagai keputusan yang terdiri atas pemikiran kritis dan penuh pertimbangan, serta penetapan dari ilmu serta pikiran kritis.
Klien tentu akan memiliki keluhan yang berbeda-beda yang dipengaruhi oleh kesehatan fisik, gaya hidup, budaya, hubungan kekerabatan, lingkungan tempat tinggal, hingga pengalaman klien itu sendiri. Oleh karena itu, perawat tidak bisa langsung mengetahui apa yang klien butuhkan, melainkan klien tersebut harus menyampaikan keluhan yang ia punya dan perawat harus banyak bertanya dan memiliki rasa ingin tahu untuk melihat suatu hal dengan perspektif yang berbeda.

\section{METODE}

Pengkajian ini menggunakan metode kualitatif yang dilakukan dengan cara mengumpulkan sebanyak-banyaknya data untuk dianalisis, yaitu dengan menggunakan literature view yang berkenaan dengan judul pembahasan yaitu mengenai Proses Pengambilan Keputysan dengan Konsep Berfikir Kritis. Adapun Literature View yang digunakan adalah Buku Teks, Buku Referensi, Jurnal Elektronik, Reasearch, dan hasil skripsi. Dengan kata kunci Peran, Kualitas Pelayanan, dan Keperawatan. Dan Literature View yang digunakan dalam metode ini adalah sebanyak 11 Literature View yang diterbitkan 8 tahun terakhir. 


\section{HASIL}

Dari 11 literature view yang telah saya baca bahwa berpikir kritis digambarkan sebagai sebuah proses, tujuan untuk membuat keputusan yang masuk akal tentang apa yang harus percaya dan apa yang harus dilakukan. Pengambilan keputusan klinis adalah sebuah proses yang melibatkan kedua penalaran diagnostik dan penilaian klinis. Tindakan dalam ini tindakan diarahkan sebagai proses refleksi dari perawat maupun pasien (Jan Florin, 2007).

Pengambilan keputusan keperawatan dilakukan pada semua tahap proses keperawatan. Sehingga seorang perawat harus mampu berpikir ktitis, berkomunikasi dengan baik sebagai suatu elemen penting dalam pengaambilan keputusan klinis, sehingga terjadi pembelajaran berkelanjutan bagi pasien sehingga meningkatkan tingkat kemandirian pasien.

\section{PEMBAHASAN}

\section{A. Konsep Berpikir Kritis}

Berpikir mencakup beberapa hal yaitu membuat pendapat, membuat keputusan, menarik kesimpulan, dan merefleksikan (Gordon, 1995 dalam Potter dan Perry, 2005). Ketika perawat mengarahkan berpikir ke arah pemahaman dan menemukan jalan keluar dari masalah kesehatan klien, prosesnya menjadi bertujuan dan berorientasi pada tujuan. Dalam kaitannya dengan keperawatan, berpikir kritis adalah reflektif, pemikiran yang masuk akal tentang masalah keperawatan tanpa ada solusi dan difokuskan pada keputusan apa yang harus diyakini dan dilakukan (Kataoka dan Saylor, 1994 dalam Potter dan Perry, 2005).

Perawat yang profesional tentunya memiliki pemikiran yang kritis dalam melakukan suatu tindakan keperawatan. Perawat sebagai bagian dari pemberi pelayanan kesehatan yaitu member asuhan perawatan dengan menggunakan proses keperawatan akan selalu dituntut untuk berpikir secara kritis dalam berbagai situasi. Berpikir kritis adalah proses yang didapat melalui pengalaman, rasa ingin tahu dan belajar terus menerus. Berpikir kritis merupakan tanda atau standar untuk perawat professional yang kompeten. Kemampuan untuk berpikir kritis akan meningkatkan praktik klinik dan mengurangi kesalahan penilaian klinis adalah visi dari praktik keperawatan (Di VitoThomas,2005). Menurut parah ahli (Potter \& Perry, 2005), berpikir kritis adalah suatu proses dimana seseorang atau individu dituntut untuk menginterfresikan atau mengevaluasi informasi untuk membuat sebuah penilaian atau keputusan berdasarkan kemampuan, menerapkan ilmu rasional terhadap ide- ide, kesimpulan, pendapat, prinsip, pemikiran, masalah, kepercayaan dan tindakan. Dalam berpikir secara kritis terdapat lima komponen model yaitu pengetahuan 
dasar, pengalaman, kompetensi berpikir kritis, perilaku dan standar. Model-model pemikiran kritis akan menjelaskan bagaimana menerapkan elemen pemikiran kritis untuk mengkaji klien, merencanakan tindakan yang akan diambil dan evaluasi hasil yang didapat. Menerapkan tiap elemen dalam berpikir tentang seorang klien dapat meningkatkan rasa percaya diri dan menjadi profesional yang efektif.

\section{B. Proses Pengambilaan Keputusan}

Proses keperawatan merupakan metode perencanaan dan pemberian asuhan keperawatan yang rasional dan sistematis secara individual untuk individu, keluarga, kelompok dan masyarakat. Tujuannya adalah untuk mengidentifikasi status kesehatan klien, masalah kesehatan yang aktual dan menyusun rencana serta intervensi keperawatan untuk menyelesaikan masalah.

Proses keperawatan memiliki karakteristik yang memungkinkan respons terhadap perubahan kesehatan klien. Karakteristik ini meliputi sifat proses keperawatan yang siklis dan dinamis, berfokus pada penyelesaian masalah, berpusat pada klien, dapat diterapkan secara universal, dan penggunaan pemikiran yang kritis (Kozier dkk, 2010).

Ada lima fase dalam proses keperawatan diantaranya pengkajian, analisis, perencanaan, implementasi, dan evaluasi. Pengkajian berupa pengumpulan, pengumpulan, pengaturan, validasi dan dokumentasi data yang sistematis dan berkesinambungan. Pengkajian keperawatan harus mencakup persepsi kebutuhan klien, masalah kesehatan, pengalaman terkait, dan praktik keperawatan.

Tahap kedua dalam proses keperawatan yaitu diagnosis. Diagnosis adalah proses analisis dan sintesis data. Pada analisis data dilakukan perbandingan antara data dan standar, mengelompokkan data dan mengidentifikasi kesenjangan dan ketidakkonsistenan data. Kemudian merumuskan pernyataan diagnosis keperawatan dan mendokumentasikan diagnosis tersebut dalam rencana asuhan keperawatan. Jika diagnosis telah selesai, maka dilanjutkan dengan perencanaan.

Perencanaan merupakan cara untuk mencegah atau menyelasaikan masalah yang teridentifikasi pada klien. Aktivitas pada proses perencanaan yaitu menetapkan prioritas dan tujuan, memilih strategi keperawatan dan rencana asuhan keperawatan. Perencanaan ini melibatkan perawat, klien, individu pendukung, dan pemberi asuhan lain. Implementasi merupakan fase dimana perawat melaksanakan intervensi keperawatan yang direncanakan. Agar berhasil dalam mengimplementasikan asuhan keperawatan, seorang perawat harus memiliki keterampilan kognitif, 
interpersonal, dan teknis. Pada proses implementasi ini biasanya mengkaji kembali klien, melakukan supervisi terhadap asuhan yang didelegasikan dan mendokumentasikan tindakan keperawatan.

Evaluasi adalah fase terakhir dalam proses keperawatan yang yang mengukur tingkat pencapaian tujuan atau hasil. Fase ini juga melakukan identifikasi terhadap faktor yang mempengaruhi pencapaian baik positif maupun negatif. Evaluasi ini berjalan kontinu. Aktivitasnya meliputi membandingkan antara data dan hasil, menarik kesimpulan tentang suatu masalah, keputusan untuk melanjutkan, memodifikasi atau mengakhiri rencana asuhan keperawatan.

\section{Berpikir Kritis dalam Pengambilan Keputusan}

Kemampuan perawat dalam berpikir kritis dapat memudahkan perawat dalam mengambil keputusan. Inilah alasan mengapa seorang perawat di tuntut untuk memiliki kemampuan dalam berpikir. Namun, kenyataan nya masih sangat sedikit perawat yang memiliki kemampuan dalam berpikir kritis.

Perawat dalam berpikir kritis melibatkan proses penalaran dan pemecahan masalah di mana semua keputusan dan penilaian klinis didasarkan pada bukti. Dalam proses ini, melibatkan intuisi, kecerdasan emosional dan refleksi. Berpikir kritis dalam keperawatan sangat dipengaruhi oleh sifat-sifat psikologis, fisiologi dan lingkungan seperti usia, tingkat kepercayaan, bias, keterampilan, stress, kelelahan, dan rekan kerja (American Society of Registered Nurses, 2007). Namun kemampuan berpikir kritis perawat dalam proses keperawatan tidak dipengaruhi oleh umur, jenis kelamin, pendidikan, pengalaman kerja dan status perkawinan (Sumartini, 2010).

Perawat merupakan pemikir kritis yang efektif, sehingga perawat diharapkan dapat melakukan asuhan keperawatan dan mampu memecahkan masalah klinis, baik yang bermanfaat bagi pasien, perawat, dan lembaga. Karena itu, dalam proses pendidikan hendaknya perawat didorong untuk mengembangkan keterampilan berpikir kritis sehingga dapat mengambil keputusan yang tepat (Rogal \& Young, 2008). Perawat dalam mengembangkan kemampuan berpikir kritrisnya selain dengan pendidikan juga dapat dikembangkan dengan metode yang lain. 


\section{KESIMPULAN}

Berpikir Kritis merupakan kemampuan yang harus ada dalam diri seorang perawat sehingga daapt dengan mudah dalam memberikan asuhan keperawatan kepada pasien serta dapat mengambil keputusan dengan baik. Faktor yang mempengaruhi Perawat dalam berfikir kritis adalah lama masa kerja, motivasi, perkembangan intelektual, kebiasaan, dan pengalaman perawat dalam melakukan asuhan keperawatan kepada pasien.

\section{SARAN}

Manajemen Rumah Sakit sebaiknya lebih mengembangkan SDM Perawat dengan memberikan kesempatan bagi perawat dalam pengembangan karir dengan meningkatkan pengetahuan berupa memberikan kesempatan bagi para perawat untuk mengikuti jenjang pendiidkan lebih tinggi dengan memberikan pelatihanpelatihan terkait wawasan perkembangan Ilmu Keperawatan.

\section{DAFTAR PUSTAKA}

Ackley, B. J., \& B, L. G. (2014). Nursing Diagnosis Handbook : An EvidenceBased Guide to Planning Care.

DeLaune, S. C., \& K, L. P. (2011). Fundamental of Nursing : Standarts anad Practice. New York: Delmar.

Deniati, K., Anugrahwati, R., \& Suminarti, T. (2018). Pengharuh Berfikir Kritis Terhadap Kemampuan Perawat Pelaksana dalam Melakukan Asuhan Keperawatan di Rumah Sakit Hermina Bekasi Tahun 2016. Jurnal Kesehatan Holistik, 12(1), 21-25.

DS, B. S., Setya, D., \& Atiningtyas. (2017). Gambaran Kemampuan Berpikir Kritis Perawat Primer dalam Pelaksanaan Asuhan Keperawatan di Rumah Sakit Islam Surakarta. Jurnal Ilmu Keperawatan Indonesia, 10(1).

Indriati. (2013). Berpikir Kritis dalam Proses Keperawatan. Jurnal Keperawatan, 6(2), 90-93.

Insani, A. A., Nurdiyan, A., Yulizawati, Elsinta, L., \& Iryanti, D. (2016, Desember). "Berpikir Kritis" Dasar Bidan Dalam Manajaemen Asuhan Keperawatan. pp. 22-24.

Khairina, I., Malini, H., \& Huriani, E. (2018). Faktor-faktor yang berhubungan dengan pengambilan keputusan Perawat dalam Ketepatan Triase di Kota Padang. Indonesiann Journal for Health Science, 2(1). 
Perry, P. A. (2010). Fundamental Of Nursing : Concept, Process, and Practice (7 ed., Vol. 3). Jakarta: Penerbit Buku Kedokteran EGC.

Ramadhiani, O. R., \& Siregar, T. (2019). Pengambilan Keputusan Klinis Perawat. Jurnal ilmiah Kesehatan, 15(2), 149-150.

Simamora, R. H. (2019). Menjadi Perawat yang CIH'HUY. Surakarta: Kekata Publisher.

Simamora, R. H. (2005). Hubungan Persepsi Perawat Pelaksana Terhadap Penerapan Fungsi Pengorganisasian Yang Dilakukan Oleh Kepala Ruangan Dengan Kinerjanya Diruang Rawat Inap RSUD Koja Jakarta Utara (Doctoral dissertation, Tesis FIK UI Tidak Dipublikasikan).

Sutriyanti, Y., \& Mulyadi. (2019). Analisis Faktor-faktor yang Mempengaruhi Penerapan Berpikir Kritis Perawat dalam Melaksanakan Asuhan Keperawatan Di Rumah Sakit. Jurnal Keperawatan Raflesia, 1(1), 24-25. 